\title{
ACCELERATED AGING IN SORGHUM GENOTYPES
}

\author{
ENVELHECIMENTO ACELERADO EM GENÓTIPOS DE SORGO
}

\author{
Fábio Batista de Lima'; Alexandre Martins Abdão dos Passos²; Josué Bispo da Silva ${ }^{3}$; \\ Charline Zaratin Alves ${ }^{4}$; Déa Alecia Martins Netto ${ }^{2}$; Mayara Fávero Cotrim ${ }^{4}$ \\ 1. Universidade Federal do Acre - UFAC, Rio Branco, AC, Brasil. fabiorm10@ gmail.com; \\ 2. Embrapa Milho e Sorgo, Sete Lagoas, MG, Brasil; 3. Universidade Federal de Mato Grosso do Sul - UFMS, Campus Três Lagoas, \\ MS, Brasil; 4. Universidade Federal de Mato Grosso do Sul - UFMS, Campus Chapadão do Sul, MS, Brasil.
}

\begin{abstract}
The accelerated aging test has stood out among vigor tests. It has been used with different objectives, including as an assistance method in the selection of cultivars for plant breeding. This research aimed to analyze the effects of different exposure times to accelerated aging on the germination and vigor of sorghum seeds from different genetic sources. The experiment consisted of a completely randomized design with eight genotypes and four replications. Seeds were subject to an accelerated aging test with four exposure times $(0,24,72$, and $96 \mathrm{~h})$ at a temperature of $47{ }^{\circ} \mathrm{C}$ and then evaluated by germination test $(\mathrm{G})$, germination speed index (GSI), mean germination time (MGT), seedling emergence (SE), emergence speed index (ESI), and mean emergence time (MET). All genotypes presented a reduction in germination, GSI, SE, and ESI, and an increase in MGT and MET. The genotype CMX5156A had an increase in seed vigor under conditions of high temperature and relative humidity. Accelerated aging for 72 hours at $47{ }^{\circ} \mathrm{C}$ drastically reduces seed vigor. The accelerated aging test can be used to differentiate sorghum genotypes in breeding programs.
\end{abstract}

KEYWORDS: Sorghum bicolor. Germination. Physiological quality.

\section{INTRODUCTION}

Sorghum is the fifth most-cultivated cereal worldwide, used in the production of grains, ethanol, and forage, and as a soil cover (COSTA et al., 2015). In Brazil, sorghum crops covered an area of 560.20 thousand hectares in the last harvest (2015/2016), producing approximately 1.17 million tons of grain, with a mean yield of $2,085 \mathrm{~kg} \mathrm{ha}^{-1}$ (CONAB, 2016). The physiological quality of its seeds is one factor related to increased crop yields, since under favorable conditions, seed quality influences the rapid establishment of uniform seedlings (NAKAGAWA, 1994).

Seed quality affects the success or failure of a crop, especially under environmental stress. Studies on seed technology have presented and discussed some shortcomings of current vigor and viability tests, revealing difficulties in acquiring and interpreting the results. Fast and reliable seed vigor determination methods have been developed to tackle these problems (ISTA, 2011). Vigor tests, such as accelerated aging, electrical conductivity, cold, and potassium leaching have been developed, improved, and used to characterize the vigor and viability of seed lots.

The accelerated aging (AA) test stands out among current vigor tests. This method is based on the seed deterioration rate, which increases considerably with exposure to high temperature and relative humidity, and therefore simulates adverse conditions to which seeds are exposed during storage or establishment in the field (AOSA, 2009).

The AA test has been performed with different objectives, such as classification of seeds lots vigor evaluation of storage potential; foundation for quality control programs; selection of lots for sowing (based on the seedlings emergence potential in field); and assistance in the selection of cultivars in plant breeding (MENON et al., 1993; ROSSETTO; MARCOS FILHO, 1995; MARCOS FILHO, 1999).

In breeding programs, AA allows selection of cultivars with higher performance potential for regions with a probability of high temperature and relative humidity during the seed maturation process. These results can also assist in the recommendation of cultivars for producers with inadequate infrastructure for seed storage.

Despite being widely used, the accelerated aging test faces some shortcomings, such as determining exposure time and temperature in the aging chamber, parameters specific to each species. Some studies carried out with sorghum seeds have used $43{ }^{\circ} \mathrm{C}$ for 72 hours (IBRAHIM et al., 1993; MIRANDA et al., 2001) or $41{ }^{\circ} \mathrm{C}$ for 96 hours (VASQUEZ et al., 2011) in the aging chamber. This work aimed to evaluate the effects of accelerated 
aging on the vigor and seed germination of different sorghum genotypes.

\section{MATERIAL AND METHODS}

This study used sorghum (Sorghum bicolor) genotypes BD1615, BRS001A, BRS511, BRS506, BRS610, CM550\35, CMX5156A, and Ponta Negra, supplied by Embrapa Produtos e Mercados. Seed samples were identified and stored in kraft paper bags, remaining in an acclimatized room at 25 ${ }^{\circ} \mathrm{C}$ throughout the study.

Seeds of each genotype were uniformly distributed in a single layer on aluminum screens fixed in plastic boxes (gerbox type, containing 40 $\mathrm{mL}$ of distilled water), which were closed and maintained at $47{ }^{\circ} \mathrm{C}$ for $0,24,72$ or 96 hours. The exposure time "zero" represented the control treatment (not subjected to aging conditions).

The water content was determined and the germination, germination rate index, mean germination time, seedling emergence, emergence speed index, and mean emergence time of the eight genotypes subjected to aging were evaluated.

The water content of the seeds was determined before aging and after each exposure time by the oven drying method, with heating at 105 $\pm 3{ }^{\circ} \mathrm{C}$ for 24 hours (BRASIL, 2009). The germination test used four replicates of 50 seeds, distributed over three sheets of germitest paper, moistened with a volume of water equivalent to 2.5 times the mass on the non-hydrated paper, and placed in plastic boxes (gerbox type). The boxes were stored in a Biochemical Oxygen Demand chamber (B.O.D), at a temperature of $25^{\circ} \mathrm{C}$.

Germination was evaluated daily for seven days, using emission of the primary root greater than $2 \mathrm{~mm}$ as a criterion (normal seedlings); germination results were expressed as a percentage. Germination speed index (GSI) and mean germination time (MGT) were determined in parallel with the germination test, based on the methods of Maguire (1962) and Labouriau (1983), respectively.

The seedling emergence test in the field used four replicates of 25 seeds, sown in 1-m-long furrows, spaced $2.5 \mathrm{~cm}$ apart, at a depth of $2.0 \mathrm{~cm}$. Counts were performed daily up to 14 days after sowing. Seeds that emitted the hypocotyl were considered to have emerged; emergence results were expressed as a percentage. Emergence speed indices (ESI) (MAGUIRE, 1962) and mean emergence time (MET), respectively, were determined in parallel with the field emergence test.

The experiment had a completely randomized design, an 8 x 4 factorial scheme (genotypes and exposure times), with four replicates. Data were subjected to an analysis of variance $(p<0.05)$ by the $F$ test. Means were compared by the Scott-Knott test, and the quantitative data were subjected to regression analysis.

\section{RESULTS AND DISCUSSION}

The water content of the different genotypes ranged from 11.2 to $12.4 \%$ before accelerated aging, in all cases less than $2 \%$, well within the tolerance range indicated for the accelerated aging test (MARCOS FILHO, 2015). No marked differences in water content were observed between the genotypes used in this study (Figure 1).

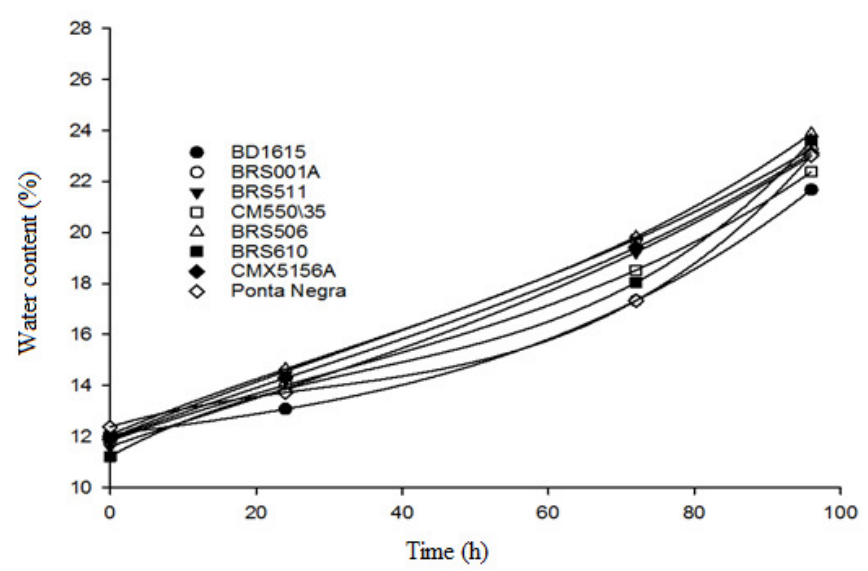

Figure 1. Water content of sorghum seeds of different genotypes before (zero) and after exposure to accelerated aging. 
After accelerated aging, the water content of the seeds reached values between 21.66 and $23.88 \%$ (Figure 1). These values were similar to those obtained by Miranda et al. (2001) for sorghum seeds aged at $41{ }^{\circ} \mathrm{C}$ for $72 \mathrm{~h}(23.8 \%)$ or $96 \mathrm{~h}(24.5 \%)$, and at $47{ }^{\circ} \mathrm{C}$ for $72 \mathrm{~h}(22.9 \%)$. Conversely, these results were lower than those obtained by Ibrahim et al. (1993), who reported mean water contents of $29 \%$ and $30 \%$ after $72 \mathrm{~h}$ of accelerated aging, at temperatures of 43 and $45{ }^{\circ} \mathrm{C}$, respectively. These differences may be related to genetic factors; i.e., the seeds used in the present work may have different hygroscopicity.

The permeability of seeds tegument may affect the high rate of water uptake during exposure to conditions of elevated temperature and relative humidity. Independent of temperature, increase in exposure time increased the water content of the seeds; water forms increasing hydration layers around the molecules until the cells reach a maximum size and the uptake process is interrupted (TAIZ; ZIEGER, 2013).

Seed vigor was affected by the exposure time to the accelerated aging test. Genotypes presented different behavior within the same exposure time for the variables germination $(\mathrm{G})$, germination speed index (GSI), mean germination time (MGT), seedling emergence (SE), emergence speed index (ESI), and mean emergence time (MET) (Table 1).

Table 1. Summary of the analysis of variance for germination percentage (G), germination speed index (GSI), mean germination time (MGT), seedling emergence percentage (SE), emergence speed index (ESI), and mean emergence time (MET) of eight sorghum genotypes after various times of exposure to accelerated aging.

\begin{tabular}{llllllll}
\hline \multirow{2}{*}{ Source of variation } & \multirow{2}{*}{ DF } & \multicolumn{7}{l}{ Mean Squares } & \multicolumn{7}{l}{$l$} \\
\cline { 2 - 7 } & & G & GSI & MGT & SE & ESI & MET \\
\hline Time (T) & 3 & $16703.041^{* *}$ & $335.6193^{* *}$ & $14.808^{* *}$ & $16087.875^{* *}$ & $135.097^{* *}$ & $14.397^{* *}$ \\
Genotype $(\mathrm{G})$ & 7 & $7678.250^{* *}$ & $78.774^{* *}$ & $14.522^{* *}$ & $8206.4821^{* *}$ & $80.108^{* *}$ & $15.261^{* *}$ \\
T x G & 21 & $347.166^{* *}$ & $3.948^{* *}$ & $4.379^{* *}$ & $334.1845^{* *}$ & $1.930^{* *}$ & $5.008^{* *}$ \\
Error & 96 & 22.390 & 0.578 & 0.077 & 14.312 & 0.269 & 0.07 \\
\hline CV $(\%)$ & & 7.97 & 13.13 & 8.84 & 6.66 & 10.52 & 7.81 \\
\hline
\end{tabular}

*, **: represent 5 and $1 \%$ significance, respectively, by the $\mathrm{F}$ test. $\mathrm{CV}$ : coefficient of variation.

The greatest linear decrease in germination between 0 and $96 \mathrm{~h}$ of aging occurred in BRS610 (85\%) and BD1615 (74\%) (Figure 2). Conversely, the genotype CM550\35 presented a quadratic decrease, with a $72 \%$ decrease in viability and a correspondingly lower germination value. BRS 511 presented no seedlings after 72 hours of accelerated aging; such behavior may be related to the relatively low vigor of these seeds prior to accelerated aging.

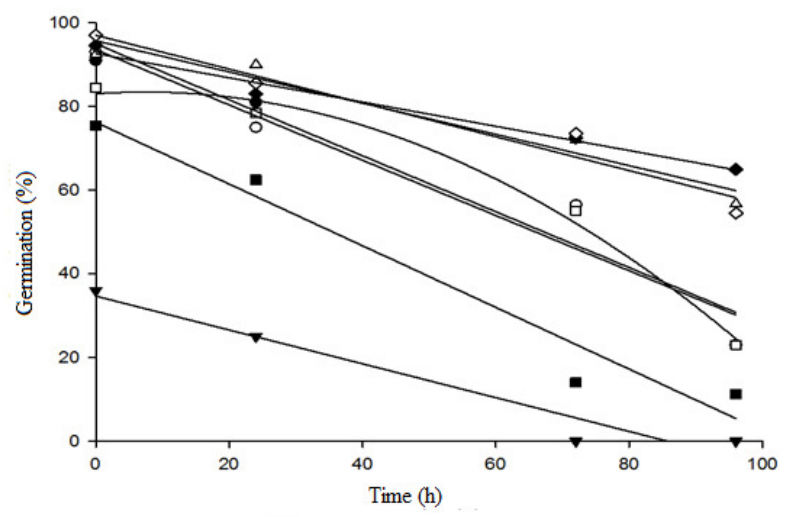

(•) BD1615 $\mathrm{y}=-0.668 \mathrm{x}+94975 \mathrm{R}^{2}(0.93)$

(०) BRS001A $y=-0.6604 x+93.57 R^{2}(0.93)$

(ㅁ) $\mathrm{CM} 550 / 35 \mathrm{y}=-0.0075 \mathrm{x}^{2}+0.1118+83.05 \mathrm{R}^{2}(0.99)$

) $\mathrm{BRS} 511 \mathrm{y}=-0.4042 \mathrm{x}+3465 \mathrm{R}^{2}(0.94)$

$(\Delta)$ BRS506 $y=-0.3938 x+97.33 R^{2}(0.97)$

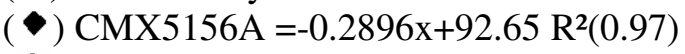

$(\diamond)$ Ponta Negra $y=-0.4042 x+92.02 R^{2}(0.95)$

( ) $\mathrm{BRS} 610 \mathrm{y}=-0.7375 \mathrm{x}+7621 \mathrm{R}^{2}(0.95)$

Figure 2. Relationship between genotype, exposure time and germination rate of sorghum seeds of different genotypes exposed to an accelerated aging test, with regression models for each genotype. 
Germination speed decreased among all genotypes with increase in exposure time (Figure 3). CMX5156A, CM550135, and BRS610 presented relatively low reductions $(42,52$ and $64 \%$, respectively), while the seeds of BD1615 showed the greatest reduction (91\%).

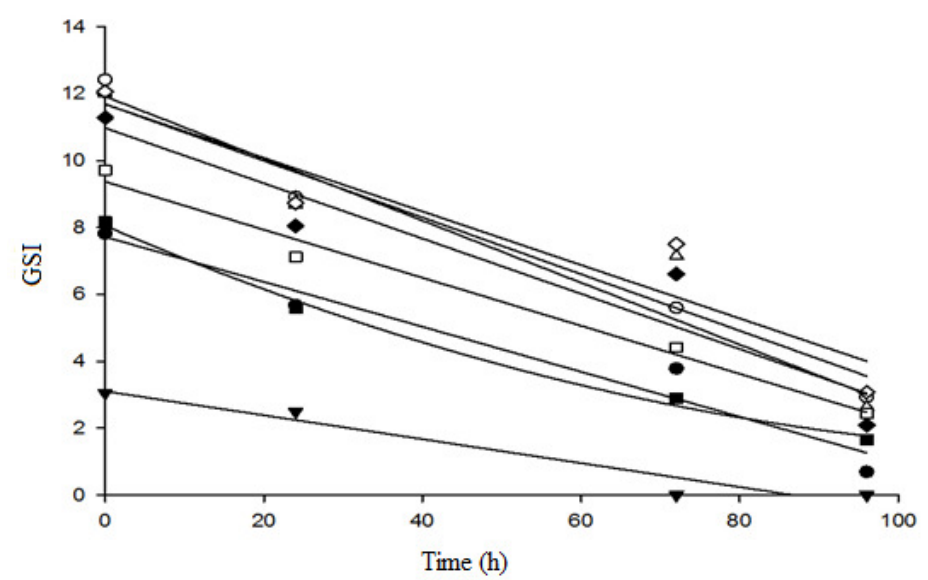
$(\bullet) \mathrm{BD} 1615 \mathrm{y}=-0.067 \mathrm{x}+7.72 \mathrm{R}^{2}(0.93)$
(०)BRS001A y $=-0.0928 \mathrm{x}+11.92 \mathrm{R}^{2}(0.98)$
( $)$ BRS511 y $=-0.358 \mathrm{x}+3.101 \mathrm{R}^{2}(0.94)$
$(\triangle)$ BRS506 $y=-0.0822 x+11.496 R^{2}(0.90)$
$($ - $)$ BRS610y $=0.0004 \mathrm{x}^{2}-0.1028 \mathrm{x}+8.057$
$\mathrm{R}^{2}(0.99)$

Figure 3. Relationship of aging exposure time to the germination speed index (GSI) of sorghum seeds of different genotypes exposed to an accelerated aging test, with regression models for each genotype.

For all genotypes, seed MGT increased with increased aging exposure time (Figure 4). SE, BRS 506, and CMX 5156 performed best (Figure 5). The ESI of BD1615 seeds decreased most $96 \%$ from 0 to
$96 \mathrm{~h}$ of exposure time (Figure 6); of the genotypes studied, BD1615 and BRS 610 required a longer exposure time to emerge (Figure 7).

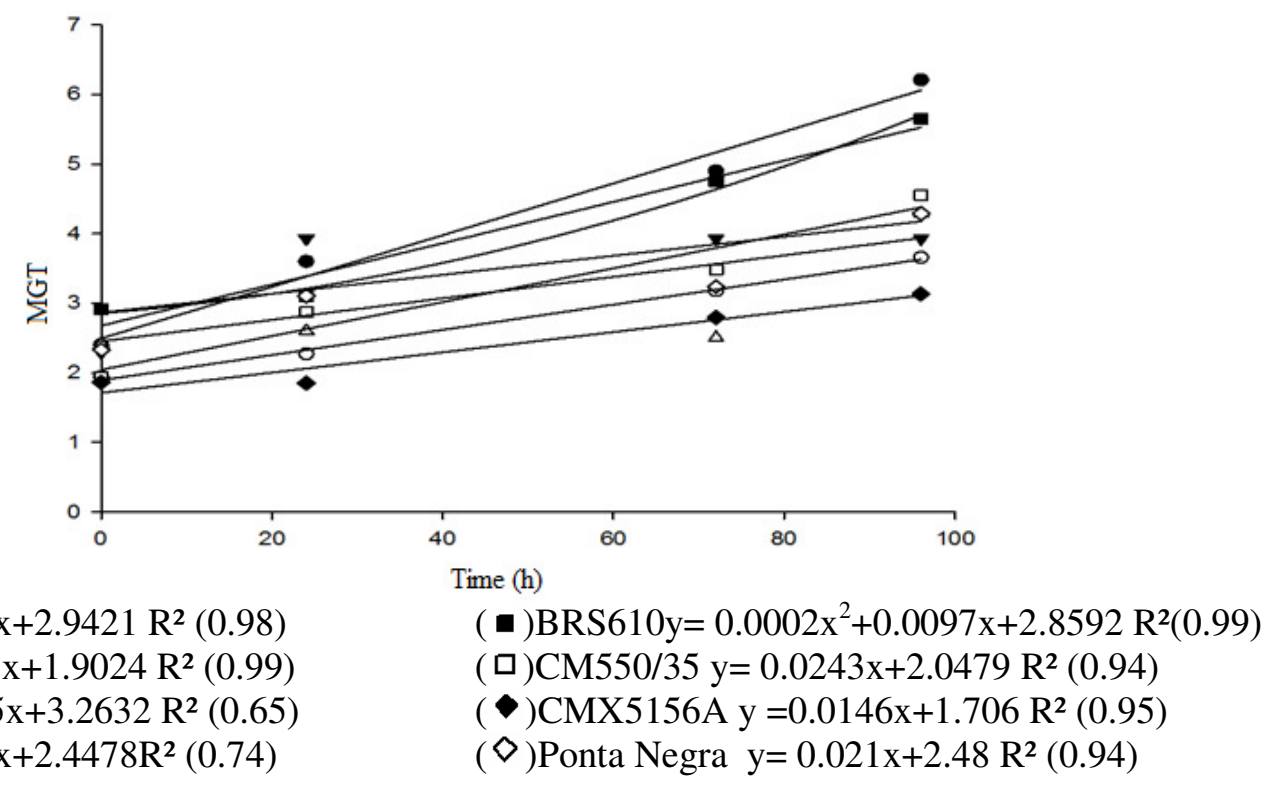

Figure 4. Relationship of different exposure times during an accelerated aging test on the Mean Germination Time (MGT) of sorghum seeds of different genotypes, with regression models for each genotype. 


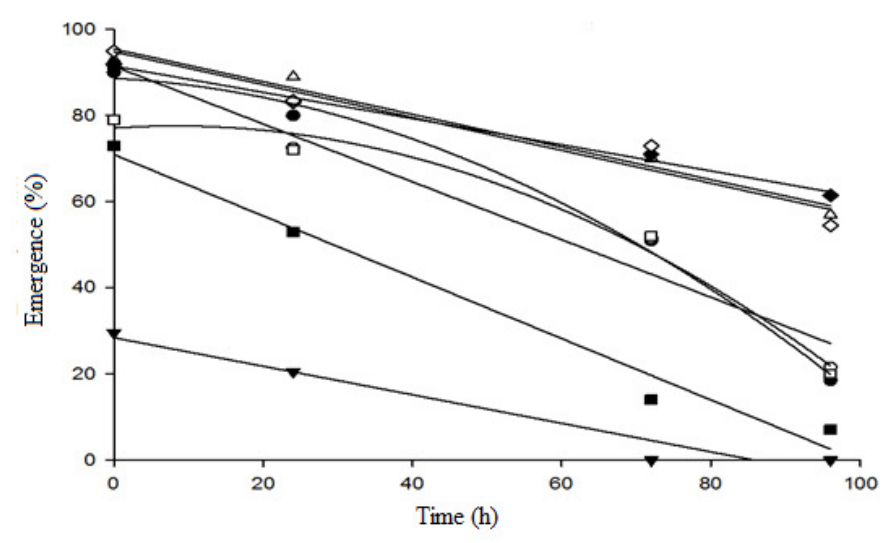
(•)BD1615 y= -0.0065 $\mathrm{x}^{2}-0.0917 \mathrm{x}+88.65$
$\mathrm{R}^{2}(0.99)$
(०)BRS001A $y=-0.6708 x+91.45 R^{2}(0.95)$
$(\nabla) B R S 511 \mathrm{y}=-0.3313 \mathrm{x}+28.4 \mathrm{R}^{2}(0.94)$
$(\Delta) B R S 506 y==-0.3958 x+96.75 R^{2}(0.98)$

( $)$ BRS610y $=-0.7125 \mathrm{x}+70.95 \mathrm{R}^{2}(0.98)$

(ㅁ) CM550/35 $y=-0.0072 x^{2}+0.1194 x+77.1 R^{2}(0.98)$

( ) CMX5156A y $=-0.3042 \mathrm{x}+91.475 \mathrm{R}^{2}(0.99)$

$(\diamond)$ Ponta Negra $y=-0.3813 x+94.8 R^{2}(0.94)$

Figure 5. Relationship of different exposure times during an accelerated aging test with the seedling emergence rate of sorghum seeds of different genotypes, with regression models for each genotype.

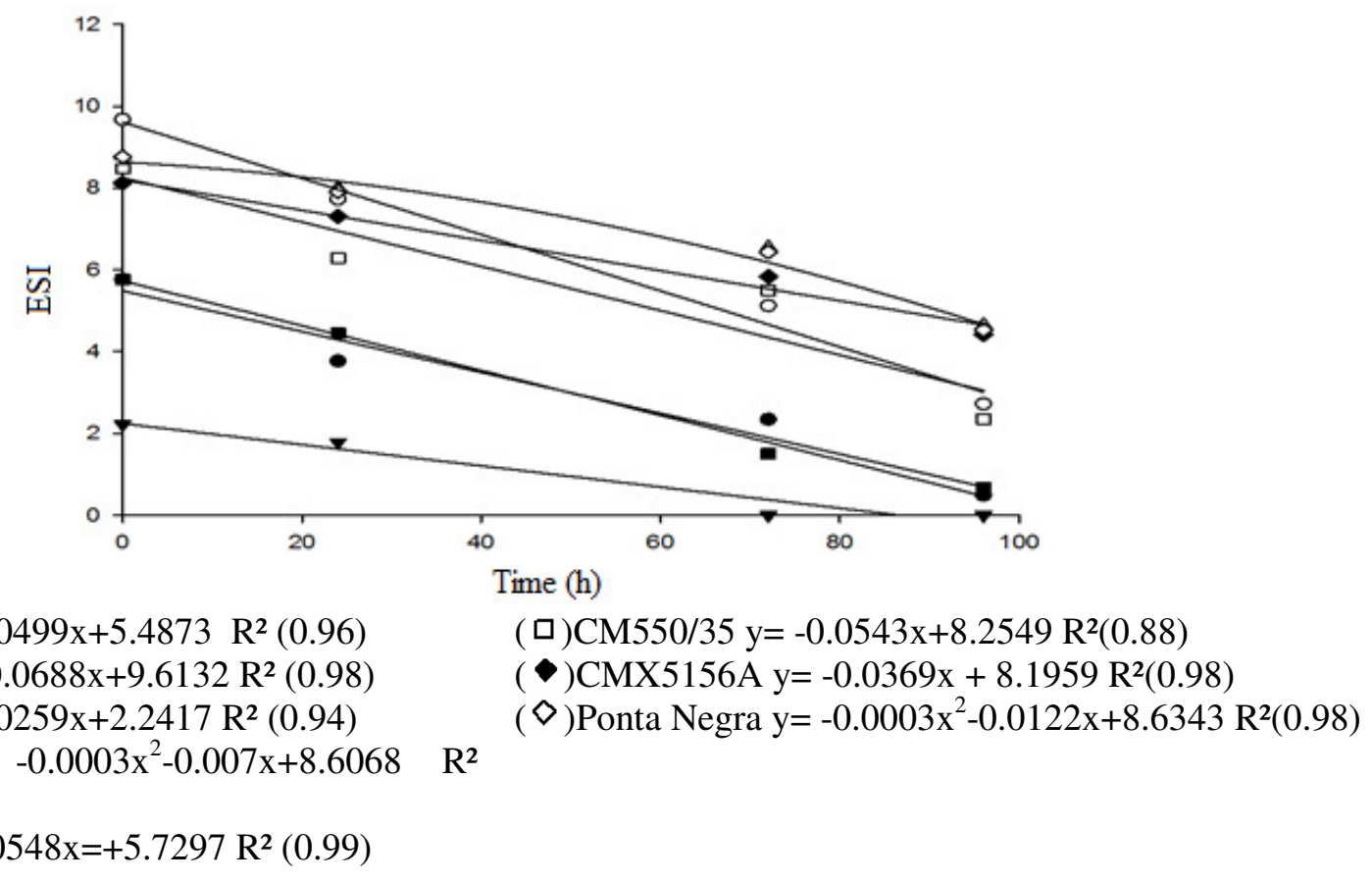

Figure 6. Relationship of different exposure times during an accelerated aging test with the Emergence Speed Index (ESI) of sorghum seeds of different genotypes, with regression models for each genotype. 


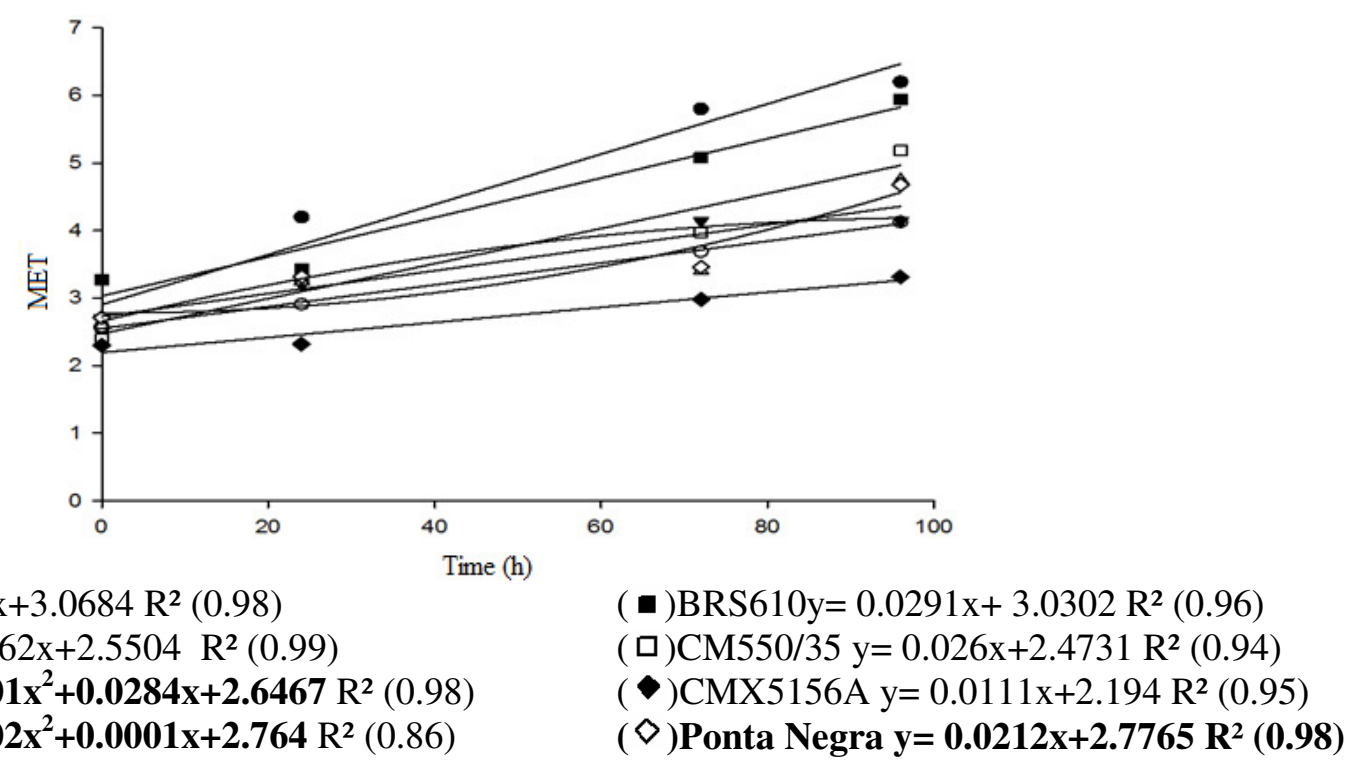

$(\bullet) \mathrm{BD} 1615 \mathrm{y}=0.038 \mathrm{x}+3.0684 \mathrm{R}^{2}(0.98)$

(O)BRS001A y $=0.0162 \mathrm{x}+2.5504 \mathrm{R}^{2}(0.99)$

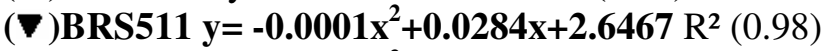

$(\Delta)$ BRS506 $y=\mathbf{- 0 . 0 0 0 2} x^{2}+0.0001 x+2.764 R^{2}(0.86)$

$(\diamond)$ Ponta Negra $y=0.0212 x+2.7765 R^{2}(0.98)$

Figure 7. Relationship of different exposure times during an accelerated aging test with the mean emergence time (MET) of sorghum seeds of different genotypes, with regression models for each genotype.

Seed germination and seedling growth are influenced by environmental factors, such as temperature, so that the lack or excess can promote biochemical and physiological changes that compromise their development and growth. Under normal conditions, cells produce reactive oxygen species (ROS) via metabolic reactions in the chloroplasts, mitochondria, and peroxisomes (MARINI et al., 2012). When ROS, such as hydrogen peroxide, are produced under normal ambient conditions, i.e., at low concentrations, they serve as signaling molecules and are essential for seed germination to occur.

ROS participate in a metabolic signaling cascade that leads to expression of genes that encode enzymes essential to the degradation of abscisic acid, a germination inhibitor. In addition, ROS play important roles in loosening seed coat and the cell wall of endosperm tissues during the radicle protrusion process (LARIGUET et al., 2013)

However, under unfavorable environmental conditions such as those seeds are exposed to during accelerated aging tests, in which the seeds remain in a medium of high humidity and temperature an imbalance between the production and consumption of ROS occurs. Thus, these molecules inevitably react with functionally important molecules including DNA, amino acids, proteins, and cell membranes, promoting their oxidation and compromising the cellular functions of tissues, reducing rates of seed germination and seedling vigor (TUNES et al., 2011).
In line with the results of this study, Miranda et al. (2001) and Ibrahim et al. (1993) showed that the water content in sorghum seeds increased with increased exposure time to accelerated aging conditions. On the other hand, they observed a reduction in germination rates and an increase in the time required for germination to occur. These results validate those obtained by Santos et al. (2004) and Binotti et al. (2008) who reported a sharp reduction in the germination of bean seeds after an accelerated aging test. The delay in seed germination after accelerated aging tests is related to the sensitivity of seeds to periods of high humidity and temperature, since these factors influence disintegration and turgescence of the membranes, leading to loss of vigor and longer germination time (DUTRA and TEÓFILO, 2007).

Although this work does not evaluate the activity of the esterase and polyphenoloxidase enzymes, the results suggest that one factor that could have contributed to the difference in vigor for both seeds and seedlings may be directly related to the antioxidant machinery (system for controlling free radicals) of each genotype. This hypothesis is justified by the observation that the genotypes that present a more efficient antioxidant system to eliminate ROS experienced less oxidative stress, preserved their embryo structures at the resumption of growth, and thus had greater seed germination, germination speed, and emergence speed, producing more vigorous seedlings.

During the seed deterioration process, the most evident initial manifestation of aging is a 
decline in germination and emergence speed, followed by a reduction in seedling size and an increase in abnormal seedlings. Rasool et al. (2013) have reported that genotypes tolerant to oxidative stress during germination have a more efficient enzymatic antioxidant system since they present higher activity of superoxide dismutase (SOD), catalase (CAT), and ascorbate peroxidase (APX) and, consequently, lower levels of lipid peroxidation.

During the accelerated aging test, reductions in seed germination and the vigor of seedlings may have been affected by both the oxidative damage and the reduction of the activity of carbohydrate metabolism enzymes, since the lower energy supply to the embryo leads to slower development, delaying radicle protrusion and seedling emergence. This helps the seeds withstand longer exposure to adverse environmental conditions. Seed damage during the accelerated aging test may be due to homeostatic imbalance during germination, which alters the energy production patterns and intensifies the generation of oxidative molecules. It can also be related to the fact that genotypes more adapted to adverse conditions present a higher ability to germinate and produce vigorous seedlings.

In general, seed germination, emergence, and vigor decreased with increase in exposure time. However, the GSI, MGT, SE, ESI, and MET tests, when performed without accelerated aging $(0 \mathrm{~h})$, form a baseline to evaluate all exposure times of the AA test as vigor tests. Thus, exposure times longer than 72 hours at $47{ }^{\circ} \mathrm{C}$ had more divergent results compared with the preliminary tests. In studies with soybean seeds (TOMES; TEKRONY; EGLI 1998; TAGLAIAFERRE et al., 2001; SILVA; VIEIRA; SANTOS, 2008), sunflower seeds (KRISHNA et al., 1997) and coffee seeds (PERTEL et al., 2003), genetic material also showed greater sensitivity to exposure times longer than $72 \mathrm{~h}$.

AA clearly differentiated genotypes with higher (CMX5156A) and lower (BRS511) potential for growth in hot and humid locations. The test is an important tool for sorghum breeding programs, since it allows detection of genotypes that produce seeds with viability equal to or above the commercialization standard $(80 \%)$, and high vigor, even under adverse conditions of high temperature and relative humidity.

\section{CONCLUSIONS}

Different sorghum genotypes have different characteristics relating to vigor loss during the accelerated aging test.

Accelerated aging at $47{ }^{\circ} \mathrm{C}$ for 72 hours leads to a drastic reduction in both the germination and vigor of sorghum seeds.

The accelerated aging test can provide useful information to sorghum-breeding programs. Sorghum genotype CMX5156A exhibits superior viability and vigor under conditions of high temperature and relative humidity.

RESUMO: O teste de envelhecimento acelerado tem se destacado entre os testes de vigor, sendo utilizado com diferentes objetivos, inclusive como método assistencial na seleção de cultivares para melhoramento de plantas. Esta pesquisa teve como objetivo analisar os efeitos de diferentes tempos de exposição ao envelhecimento acelerado na germinação e vigor de sementes de sorgo de diferentes fontes genéticas. $\mathrm{O}$ experimento consistiu em um delineamento inteiramente casualizado com oito genótipos e quatro repetições. As sementes foram submetidas ao teste de envelhecimento acelerado com quatro tempos de exposição $(0,24,72$ e $96 \mathrm{~h})$ a uma temperatura de $47{ }^{\circ} \mathrm{C}$ e avaliadas pelo teste de germinação (G), índice de velocidade de germinação (GSI), tempo médio de germinação. (MGT), emergência de plântulas (SE), índice de velocidade de emergência (ESI) e tempo médio de emergência (MET). Todos os genótipos apresentaram redução na germinação, GSI, SE e ESI, e aumento no MGT e MET. O genótipo CMX5156A apresentou sementes com maior vigor em condições de alta temperatura e umidade relativa. O envelhecimento acelerado por 72 horas a $47{ }^{\circ} \mathrm{C}$ reduz drasticamente o vigor das sementes. $\mathrm{O}$ teste de envelhecimento acelerado pode ser usado para diferenciar genótipos de sorgo em programas de melhoramento.

PALAVRAS-CHAVES: Sorghum bicolor. Germinação. Qualidade fisiológica

\section{REFERENCES}

ASSOCIATION OF OFFICIAL SEED ANALYSTS. Testing Handbook. Contribution Lincoln: AOSA, 2009. 105p. (Contribution, 32). 
BINOTTI, F. F. S.; HAGA, K. I.; CARDOSO, E. D.; ALVES, C. Z.; SÁ, M. E. Efeito do período de envelhecimento acelerado no teste de condutividade elétrica e na qualidade fisiológica de sementes de feijão. Acta Scientiarum, Recife, v. 30, n. 2, p. 247-254, 2008. https://doi.org/10.4025/actasciagron.v30i2.1736

BRASIL. Ministério da Agricultura, Pecuária e Abastecimento. Regras para análise de sementes. Brasília, DF: MAPA/ACS, 2009.

CONAB - COMPANHIA NACIONAL DE ABASTECIMENTO. Acompanhamento da safra brasileira de grãos. v. 1 - Safra 2015/16, n.6 - Sexto Levantamento, Brasília, p. 1-103, 2016.

COSTA E. J. B.; SOUZA, E. S.; BARROS JUNIOR, G.; NUNES FILHO, J.; SOUZA J.; TABOSA, J. N. R. Cultivo de sorgo em sistema de vazante com e sem cobertura do solo. Revista Brasileira de Milho e Sorgo, Sete Lagoas, v. 14, n. 2, p. 182-195, 2015.

DUTRA, A. S.; TEÓFILO, E. M. Envelhecimento acelerado para avaliar o vigor de sementes de feijão-caupi. Revista Brasileira de Sementes, Londrina, v. 29, n. 1, p. 193-197, 2007. https://doi.org/10.1590/S010131222007000100027

IBRAHIM, A. E.; TEKRONY, D. M.; EGLI, D. B. Accelerated aging techniques for evaluating sorghum seed vigor. Journal of Seed Technology, Lincoln, v. 17, n. 1, p. 29-37, 1993.

ISTA. International Rules For Seed Testing Association, Zurich. 2011.

LABOURIAU, L. G. A germinação das sementes. Washington: Secretaria Geral da Organização dos Estados Americanos, 1983. 174p.

KRISHNA, A.; JAGADASHI, G. V.; DESHPANDE, V. K.; PRASANNA, K. P. R.; VENKATARAMAN. Effect of seed vigor levels on field performance and relationship between seed vigor tests and field emergence in sunflower hybrids. Karnataka Journal of Agricultural Sciences, Karnataka, v. 10, n. 1, p. 112-116, 1997.

LARIGUET, P.; RANOCHA, P.; MEYER, M.; BARBIER, O.; DUNAND, C. Identification of a hydrogen peroxide signalling pathway in the control of light-dependent germination in Arabidopsis. Planta, v. 238, n. 2, p. 381-395, 2013. https://doi.org/10.1007/s00425-013-1901-5

MAGUIRE, J. D. Speeds of germination-aid selection and evaluation for seedling emergence and vigor. Crop Science, Madison, v. 2, p. 176-177, 1962. https://doi.org/10.2135/cropsci1962.0011183X000200020033x

MARCOS FILHO J. 1999. Teste de envelhecimento acelerado. In: KRZYZANOWSKI FC; VIEIRA R. D; FRANÇA NETO J. B (eds). Vigor de sementes: conceitos e testes. Londrina: ABRATES. p. 1-24.

MARCOS-FILHO, J. Fisiologia de sementes de plantas cultivadas. Londrina: ABRATES, 659 p, 2015.

MENON, J. C. M.; BARROS, A. C. S. A.; MELLO, V. D. C.; ZONTA, E. P. Avaliação da qualidade física e fisiológica das sementes de soja produzidas no Estado do Paraná na safra 1989/90. Revista Brasileira de Sementes, Brasília, v. 15, n. 2, p. 203-208, 1993. https://doi.org/10.17801/0101-3122/rbs.v15n2p203-208

MARINI, P.; MORAES, C. L.; MARINI, N.; MORAES, D. M.; AMARANTE, L. Alterações fisiológicas e bioquímicas em Sementes de arroz submetidas ao estresse térmico. Revista Ciência Agronômica, v. 43, p. 722-730, 2012. https://doi.org/10.1590/S1806-66902012000400014

MIRANDA, D. M.; NOVEMBRE, A. D. L. C.; CHAMMA, H. M. C. P. Avaliação do potencial fisiológico de sementes de sorgo pelo teste de envelhecimento acelerado. Revista Brasileira de Sementes, Brasília, v. 23, n. 1, p. 226-231, 2001. https://doi.org/10.17801/0101-3122/rbs.v23n1p226-231 
NAKAGAWA, J. Testes de vigor baseados na avaliação das plântulas. In: VIEIRA, R. D., CARVALHO, N. M. (Ed.) Testes de vigor em sementes. Jaboticabal: FUNEP, 1994. p. 49-85.

PERTEL, J.; DIAS, D. C. F. S.; BORGES, E. E. L.; DIAS, L. A. S.; NAVEIRA, D. P. Alterações nos ácidos graxos durante o envelhecimento artificial de sementes de café (Coffea arabica L.). Informativo ABRATES, Brasília, v. 13, n. 3, p. 81, 2003.

RASOOL, S.; AHMAD, A.; SIDDIQI, T. O.; AHMAD, P. Changes in growth, lipid peroxidation and some key antioxidant enzymes in chickpea genotypes under salt stress. Acta physiologiae plantarum, v. 35, n. 4, p. 1039-1050, 2013. https://doi.org/10.1007/s11738-012-1142-4

ROSSETTO, C. A. V.; MARCOS FILHO, J. Comparação entre os métodos de envelhecimento acelerado e de deterioração controlada para avaliação da qualidade de sementes de soja. Scientia Agricola, Piracicaba, v. 52, n. 1, p. 123-131, 1995. https://doi.org/10.1590/S0103-90161995000100020

SANTOS, C. M. R.; MENEZES, N. L.; VILLELA, F. A. Alterações fisiológicas e bioquímicas em sementes de feijão envelhecidas artificialmente. Revista Brasileira de Sementes, Londrina, v. 26, n. 1, p. 110-119, 2004. https://doi.org/10.1590/S0101-31222004000100017

SILVA, M. A. D.; VIEIRA, R. D.; SANTOS, J. M. Influência do envelhecimento acelerado na anatomia da testa de sementes de soja, cv. Monsoy 84001. Revista Brasileira de Sementes, Brasília, v. 30, n. 2, p. 91-99, 2008. https://doi.org/10.1590/S0101-31222008000200012

TAGLIAFERRI, C.; RANGEL, O. J. P.; LOPES, J. C.; MARTINS-FILHO, S.; CAPUCHO, M. T.; LIMA, J. S. S. Avaliação de genótipos de soja (Glicine max L. Merrill) através do teste de envelhecimento acelerado. Informativo ABRATES, Londrina, v. 11, n. 2, p. 228, 2001.

TAIZ, L.; ZEIGER, E. Fisiologia vegetal. 5. ed. Porto Alegre: Artmed, 2013. 954p.

TOMES, L. J.; TEKRONY, D. M.; EGLY, D. B. Factotes influencing the tray accelerated ageing test for soybean seed. Juornal of seed Technology, Lansing, v. 12, n.1, p.23-35, 1988.

TUNES, L. M.; PEDROSO, D. C; BARBIERI, A. P. P.; CONCEIÇÃO. G. M.; ROETHIG, E.; MUNZ, M. F. B.; BARROS, A. C. S. A. Envelhecimento acelerado modificado para sementes de coentro (Coriandruim sativum L.) e sua correlação com outros testes de vigor. Revista Brasileira de Biociências, Porto Alegre, v. 9, n.1, p. 12-17, 2011.

VASQUEZ, G. H.; BERTOLIN, D. C.; SPEGIORIN, C. N. Testes de envelhecimento acelerado e de condutividade elétrica para avaliar a qualidade fisiológica de sementes de sorgo (Sorghum bicolor (L.) Moench). Revista Brasileira de Biociências, Porto Alegre, v. 9, p. 18-24, 2011. 